DOI 10.4467/2543733XSSB.16.001.6243

\author{
ALEKSANDER W. LIPATOW
}

Rosyjska Akademia Nauk

\title{
ROSYJSKOŚĆ I POLSKOŚĆ W ŚWIETLE CYWILIZACYJNEJ AKSJOLOGII EUROPEIZMU
}

Słowa kluczowe: europeizm, rosyjskość, polskość, propolskie nastroje w Rosji

Poszczególne zjawiska składające się na tę sumę wydarzeń i procesów, którą nazywamy historią, tworzą całość bynajmniej nie spójną. Jej składowe stanowią byty osobne, zaś stąd kontrowersyjne i skonfliktowane, co znajduje odbicie w sprzecznościach państwowych, religijnych, narodowych, starciach społecznych i zbrojnych. Absolutyzacja jednej z tych części składowych w procesie tworzenia ogólnego obrazu historii zniekształca tę historię, ponieważ świadomie lub bezwiednie porządkuje różnorodną realność zgodnie z określoną koncepcją ideologiczną. Tam zaś, gdzie rozpoczyna się ideologia, kończy się nauka jako poszukiwanie i w miarę możliwości zyskiwanie prawdy obiektywnej.

Patrząc wstecz z naszej współczesności na przeszłość naszej Europy w kategoriach czasu długiego trwania, „krótki” wiek XX staje przed oczyma jako kolejny „bilans” naszej cywilizacji. Stąd logiczne wydaje się uświadomienie go sobie przez pryzmat tej pierwotnej idei i wyobrażeń z nią związanych, które przeobraziły Europę jako pojęcie geograficzne czasów antycznych w Europę jako cywilizację. Christianitas stanowi punkt wyjścia tego uniwersalnego ujmowania świata, które zbliżało rozproszone plemiona jednego kontynentu na podstawie wspólnej i spójnej aksjologii, przesądzając o kształtowaniu europejskiej kultury, a w jej ramach europejskich narodów i europejskich państw.

W systemie ogólnocywilizacyjnego światopoglądu pierwiastki uniwersalne i lokalne (etniczne, zaś w dalszej perspektywie - narodowe) stanowiły jedność dialektyczną. Dychotomiczny ich podział wskutek państwowego, etnicznego, religijnego etc. rozwoju pierwiastków lokalnych oznaczał rozłam pierwotnej istoty Christianitas. Apogeum tego długotrwałego procesu historii cywilizacji europejskiej stanowił tragiczny wiek XX.

Dwie wojny światowe, genocydy i Holocaust - owe zbiorowe samobójstwa Europy, masowe ludobójstwa według kryteriów narodowościowych lub klasowych dokonane przez reżimy totalitarne, które niszczyły prawa naturalne człowieka i dławiły w człowieku osobowość - to wszystko stanowiło samozaprzeczenie cywilizacji. 
Historyczna deformacja europeizmu, wypaczenie jego pierwotnej istoty prowadziło ku narodowym i religijnym podziałom Europejczyków, do szowinizmu i wrogości, stwarzanych przez instytucje państwa i Kościoła. Te procesy ogólnoeuropejskie wycisnęły piętno na lokalnych procesach jako ich pochodnych. Trudne rosyjsko-polskie sąsiedztwo ${ }^{1}$ jest właśnie lokalnym przejawem historii ogólnoeuropejskiej. W świetle dzisiejszych dążeń Europejczyków do wzajemnego zrozumienia oraz w warunkach deideologizacji nauki uświadomienie sobie sąsiedztwa dwóch słowiańskich narodów jest możliwe poza absolutyzacją tego czy innego z poszczególnych składników historii. Trzeba pamiętać, że oznacza to również osobne - poza absolutyzacją ideologiczną czy uogólnieniem polityki historycznej - rozpatrzenie samych tych składników (w tym również samej ideologii i polityki historycznej jako ich części naturalnych), a także specyfiki ich współistnienia, współdziałania i oddziaływania.

Przeanalizowanie tego kompleksu zagadnień we wspólnym dla Polaków i Rosjan kontekście cywilizacji oraz w świetle właściwej jej aksjologii będzie sprzyjało rozumieniu realności w jej wielowymiarowej złożoności, nie zaś ideologicznie ograniczonej jednoznaczności i - na tej jednowymiarowej płaszczyźnie - doktrynalnie zaangażowanych koncepcji polityki historycznej, w których dialektyczność współpowiązania pierwiastków uniwersalnych $\mathrm{z}$ narodowymi zamienia się $\mathrm{w}$ ich dychotomię. Oczywiście cywilizacyjno-kulturowe podejście pozwala uświadomić sobie sięgający XVII w. fenomen rosyjskiego polonofilstwa. W tamtym stuleciu wojennych, politycznych i religijnych konfliktów między Rosją i Rzeczypospolitą, równolegle z tą wszechobejmującą wrogością, obok niej i wbrew niej, pojawia się i szybko pogłębia rosyjskie pasjonowanie się polskością. Stając się modą (która z samej swej istoty jest irracjonalna, zaś stąd apolityczna i pozakonfesjonalna), tego rodzaju polonofilstwo ogarnia tak wysoką, jak masową (popularną, miejską) kulturę.

Szymon Połocki, przybyły do Moskwy z Rzeczypospolitej w 1664 r., zauważył ze zdziwieniem, że tu wielu polubiło ,słodkie i harmonijne śpiewanie polskiego Psałterza wierszem przełożonego”, zaś niektórzy aczkolwiek śpiewali „mało albo wcale nie znając” polskiego, to z powodu ,pięknego śpiewu podnosząc się na duchu”"2. Po upływie trzech stuleci A. Pozdniew, duchowny prawosławny, znalazł ponad 500 rękopiśmiennych zbiorów z XVII-XVIII w., w których, prawdopodobnie ze słuchu, cyrylicą były spisane polskie pieśni³

Język polski stał się językiem najlepiej wykształconej części rosyjskiego środowiska i dworu carskiego. Z polskiego thumaczono utwory literackie ${ }^{4}$, które w narodowej kulturze odzwierciedlały uniwersalne wartości zachodnioeuropejskiej kultury Odrodzenia i Baroku. W XVII w. to właśnie kultura polska odegrała zasadniczą rolę w rosyjskim przezwyciężaniu przedłużającego się Średniowiecza ${ }^{5}$. Istota tego zjawiska polega na tym, że polskość dla rosyjskości była lustrem współczesnego europeizmu, a jednocześnie wzor-

1 А. В. Л ип атов, Трудное соседство. Поляки и русские: взаимопоимание, Москва 2000.

2 Симеон Полоцк и й, Избранные произведения, Москва-Ленинград 1953, С. 213.

3 А. Позднев, Рукописные песенники XVII-XVIII вв., Москва 1958; Он же, Светские польские песни в русских рукописных песенниках XVII в. Польско-русские литературные связи, Москва 1970.

${ }^{4}$ С.И. Н и кол ае в, Польская поэзия в русских переводах. Вторая половина ХVII - первая третв XVIII века, Ленинград 1989.

${ }_{5}^{5}$ А.В. Л и п а то в, Литературный облик польского Барокко и проблемы изучения древнерусской литературы. Славянское Барокко. Историко-культурное проблемы эпохи, Москва 1979; A.W. L i patow, Rosja i Polska: Konfrontacja i grawitacja. Historia. Kultura. Literatura. Polityka, Torun 2003; С.И. Н и кол а в, Польско-русские литературные связи XVI-XVIII веков и их значение для русской литературы. Славяноведение, 2002, N. 2. 
cem jego swoistego przetworzenia w kulturze słowiańskiego sąsiada. Jego kultura była postrzegana jako swojego rodzaju artystyczne i obyczajowe wcielenie nowych czasów Europy Zachodniej, dlatego język tego sąsiada był pośrednikiem w procesie przyswajania europejskości przez rosyjskość. W wieku XVII język polski wszedł do programu Akademii Słowiańsko-Grecko-Łacińskiej w Moskwie; władali nim twórcy nowoczesnej rosyjskiej kultury, nauki i literatury wieku XVIII, w tym reformatorzy rosyjskiej poezji M.W. Łomonosow i W.K. Triediakowski.

„Zewnętrznie” - na tle państwowych, religijnych, wojennych konfliktów Rosji i Rzeczypospolitej - polonofilstwo rosyjskie wygląda na paradoks. Zaś ujmowane „wewnętrznie" - na płaszczyźnie kultury europejskiej i właściwej jej percepcji - ukazuje się jako lokalny przejaw uniwersalnej prawidłowości. Inaczej mówiąc: postrzegane w aspekcie właściwej mu aksjologii polonofilstwo rosyjskie jawi się jako naturalna i organiczna część składowa wewnątrzcywilizacyjnego obiegu wartości, będącego w kulturze, nauce, sztuce i literaturze procesem ogólnoeuropejskim, który przesądza o kształtowaniu i zmianie epok historycznych (Średniowiecze, Odrodzenie, Barok, Oświecenie etc.).

Tak ujmowana uniwersalność europeizmu istnieje poza partykularyzmem państwowym, narodowym, religijnym, partyjno-politycznym i innych ośrodków tej czy innej władzy. Właśnie ona, gwoli własnym potrzebom, wytwarza ideologię, w której dialektyczność powiązań wzajemnych pierwiastków uniwersalnych (ogólnocywilizacyjnych) i lokalnych państwowych, narodowych, religijnych etc.) zamienia się w ich dychotomię - zróżnicowana jedność przekształca się w dwudzielność.

Ideologie rozczłonkowują Europę jako cywilizację wbrew tej uniwersalnej - wszechobejmującej, powszechnej, ogólnoludzkiej i ludzkiej idei, która tę cywilizację stworzyła. Historycznie sąsiedztwo Rosji i Polski to tylko poszczególne odbicie wspomnianej ogólnoeuropejskiej prawidłowości. Wywoływane przez ideologie polityczne, religijne, narodowe konfrontacje mają kontrowersyjną wobec nich paralelę w kulturowej grawitacji, która wywodzi się z aksjologii ogólnocywilizacyjnej. Uświadomienie sobie takiego paralelizmu umożliwia spojrzenie na wspólną polsko-rosyjską - historię w szerokiej ogólnocywilizacyjnej perspektywie, czyli poza wąskimi ograniczeniami jakiejkolwiek interpretacji ideologicznej. A to z kolei pomoże w zrozumieniu historycznie kolejnych - zewnętrznych, ponieważ pozornych - paradoksów rosyjskiego polonofilstwa.

W przeciągu XVIII w. Rosja wskutek rozpoczętych przez Piotra I radykalnych reform przeistoczyła się - według słów Katarzyny II - w „mocarstwo europejskie”. Przyspieszone i dynamiczne przeobrażenie carstwa moskiewskiego w imperium petersburskie zostało oparte na takiej kulturze, która miała stworzyć fenomen „rosyjskiego Europejczyka” - zdaniem Piotra I, budowniczego „rosyjskiej Europy”. Ta nowa kultura - jako siła napędowa rewolucyjnej modernizacji państwa - była wynikiem ewolucyjnego rozwoju tej części kultury wysokiej w wieku XVII, której twórcami i nosicielami byli rosyjscy polonofile.

Ponieważ w ciągu XVIII w. poziom wysokiej kultury Rosji zaczyna dorównywać wysokiej kulturze Polski, zmienia się rola polskości, która dotąd pośredniczyła w przekazywaniu kultury wysokiej - rosyjskość staje się odtąd jej równoprawnym partnerem. W pierwszej połowie stulecia, na tle dyskusji o reformowaniu Rzeczypospolitej, znajduje to w szczególności odbicie w zainteresowaniu polskiej publicystyki rosyjskim doświadczeniem w przeprowadzeniu ogólnych przemian ustrojowych, zaś w drugiej połowie wieku - w czasach rozkwitu kultury, literatury i sztuki epoki Oświecenia w Rosji 
i w Polsce - w ukazaniu się pierwszych polskich tłumaczeń poezji rosyjskiej i początkach osobistych kontaktów polskich i rosyjskich twórców. Charakterystyczny fakt: znane wypadki polityczne - jak w czasach poprzednich - nie stanowiły przeszkody dla już tradycyjnego polonofilstwa rosyjskiego, przy czym teraz uzyskało ono nowy wymiar. Wraz z kształtowaniem się w Rosji społeczeństwa obywatelskiego (którego pierwszymi głosicielami byli Nikołaj Nowikow i Aleksander Radiszczew, zaś pierwszym czynem powstanie dekabrystów) polonofilów rosyjskich zaczęły łączyć z polskością uniwersalne idee ogólnoeuropejskiego Oświecenia i aktualizowane tradycje historii narodowej - Republiki Nowogrodzkiej z lat 1136-1478 i demokracji szlacheckiej6.

„Rosyjska inteligencja - pisał N.A. Bierdiajew - od końca XVIII w., od Radiszczewa dusiła się w państwowości samodzierżawnej i szukała wolności i prawdy w życiu społecznym" ". Ponieważ w tym czasie Polacy byli przytłoczeni przez ten sam system państwowy, zarówno ich dążenia do odzyskania niepodległości, jak realizacji uniwersalnych idei epoki Oświecenia były zrozumiałe i bliskie rosyjskim przedstawicielom społeczeństwa obywatelskiego. Właśnie tak rozumiany europeizm łączył takich Rosjan i takich Polaków w sferze kultury, a tym samym polityki jako jej pochodnej. Popularny ówcześnie poeta, przyszły dekabrysta K.F. Rylejew, świetnie władający językiem polskim, pisał do niedawnego więźnia Twierdzy Pietropawłowskiej, J.U. Niemcewicza:

Zamiłowanie prawdy i wszystkiego, co jest ojczystym, natchnęło mi zamiar podania uwadze ziomków moich wielkie bohaterów rosyjskich czyny i przyjaciół całego narodu Człowieka. Śpiewy historyczne J.W. Pana były dla mnie wybornym wzorem, dla któregom się nauczył języka ozdobionego imionami Kochanowskich, Krasickich, Trembeckich i Niemcewiczów.

Dalej, poświęcając Niemcewiczowi własny przekład Dumy o kniaziu Michale Glińskim jego autorstwa, zaznaczył:

Płody geniuszu są spólną wszystkich własnością: ja zaś śmiem zaręczać Szanownego Nestora polskiej literatury, że na brzegach Newy młodociane w królestwie nauk pokolenie z rozkoszą się napawa słodkim sarmackiej lutni dźwiękiem i umie cenić przyjaciół wielkiego Washingtona ${ }^{8}$.

Tu wyraźnie widać, że w uniwersalnym kręgu cywilizacji europejskiej Rosjanie i Polacy są sobie bliscy tak pod względem kulturowym, jak społeczno-politycznym. Europeizm rosyjskiego społeczeństwa obywatelskiego - jego demokratyczne i liberalne części składowe - powodował, że w sposób niezmiernie krytyczny odnosiło się ono do systemu państwowego własnej ojczyzny. „W ogromnej sprawie tworzenia i ochrony swojego państwa naród rosyjski zużywał swoje siły - pisał N.A. Bierdiajew. - Cała zewnętrzna działalność człowieka rosyjskiego była zmuszana do służenia państwu. I to odcisnęło smutne piętno na życiu rosyjskiego człowieka"".

${ }^{6}$ A. Li patow, Rosja i Polska: Konfrontacja i grawitacja. Historia. Kultura. Literatura. Polityka, Toruń 2003; I d e m, Stowiańszczyzna - Polska - Rosja. Studia o literaturze i kulturze. Izabelin 1999; I d e m, Rosyjskie projekcje europeizmu a czynnik polski (od średniowiecza do epoki nacjonalizmów), Prace Komisji Spraw Europejskich PAU, t. V, Kraków 2012.

7 Н.А. Бе р дя я в, Руская идея. О России и русской филосовской культуре: Философы русского послеоктябрьского зарубежья, Москва 1990, С. 170.

${ }^{8}$ Cyt. za: A. K ra u s har, Obrazy i wizerunki historyczne, Warszawa 1906, s. 330.

9 Н.А. Бе ердяе в, Анархизм - явление русского духа. Русский индивидуализм, Москва 2007, С. 175. 
Uwzględnienie czynnika świadomości własnej społeczeństwa obywatelskiego, który łączył w uniwersalnym kręgu europeizmu Rosjan i Polaków, usuwa kolejny, i znów pozorny, paradoks ich wspólnego przeciwstawiania się państwu rosyjskiemu. Ta pozorność jest wynikiem takiej koncepcji historii, która przedstawia przeszłość tylko na jednej płaszczyźnie - narodowo-ustrojowej ideologii i interpretuje wyłącznie w świetle kolejnych potrzeb tego, co w naszych czasach uzyskało miano ,polityki historycznej”"10. Jedyna różnica we wspólnym rosyjsko-polskim sprzeciwie wobec tego samego systemu ustrojowego polegała na tym, że Rosjanie zmagali się z własnym państwem, żeby je przekształcić w duchu europejskiej współczesności, Polacy zaś walczyli przeciwko obcemu dla nich państwu, ażeby odzyskać państwowość i przeprowadzić ogólnoeuropejskie w swej istocie reformy. Niestety reformy zapoczątkowane przez Konstytucję 3 maja w 1791 roku zostały zniweczone przez trzy monarchie absolutne, które dokonały rozbioru Polski.

Dekabryści wystąpili w 1825 roku przeciwko temu samemu imperatorowi i temu samemu imperium, przeciwko którym pięć lat później chwycili za broń Polacy. Stąd bynajmniej nie było paradoksalne wezwanie „O wolność naszą i waszą”, jak również masowa manifestacja w wyzwolonej Warszawie 25 stycznia 1831 roku, kiedy tłum niósł pięć symbolicznych trumien dla uczczenia pięciu straconych dekabrystów. Mickiewicz, który poznał Rosję od środka, przenikliwie ukazał w Dziadach trzy Rosje - Rosję społeczeństwa obywatelskiego - owych „Przyjaciół Moskali”, dekabrystów, Rosję podległego i upodlonego społeczeństwa upaństwowionego i Rosję ludu, który jeszcze nie przejrzał na oczy $^{11}$. Taki zróżnicowany stosunek do Rosjan - z tymi czy innymi odchyleniami (w zależności od chwili historycznej) utrzymuje się w ciągu polsko-rosyjskiej historii po dziś dzień. Natomiast przykładem rosyjskiej paraleli widzenia Polaków w świetle uniwersalnej kultury europeizmu i społeczno-politycznych poglądów społeczeństwa obywatelskiego są wspomnienia A.I. Hercena z 1851 roku:

Kiedy wybuchła w Warszawie rewolucja 1830 roku, naród rosyjski nie wykazał najmniejszej nawet wrogości wobec winnych nieposłuszeństwa woli carskiej. Pamiętam, z jaką niecierpliwością czekaliśmy na wiadomości z Warszawy: płakaliśmy jak dzieci na wiadomość o stypie wyprawionej w stolicy Polski ku pamięci naszych petersburskich męczenników. Współczucie Polakom naraziło nas na okrutne kary - mimo woli trzeba było ukrywać go w sercu i milczeć' ${ }^{22}$.

W kulturowym, a przede wszystkim artystycznym i obyczajowym ustosunkowaniu Rosjan do polskości rozgraniczenie społeczeństwa obywatelskiego i upaństwowionego traciło określoność albo zupełnie się zacierało. Za przykład może służyć pierwsza rosyjska opera romantyczna o wyraźnym oficjalno-patriotycznym ukierunkowaniu, którego odzwierciedleniem był już sam tytuł - Życie za cara (1836) M. Glinki. Przez blisko dwa wieki olśniona publiczność po podniesieniu kurtyny żywiołowo wybucha oklaskami na widok „aktu polskiego" - polskich szat narodowych, szlacheckich postur i towarzyszących temu barwnemu widowisku dźwięków mazurka. Widoczne piękno polskości tłumi świadomość

${ }^{10}$ A. Li p a to w, Historia a polityka historyczna, Prace Komisji Środkowoeuropejskiej PAU, T. XXI, Kraków 2013.

11 A. Li p a to w, Rosja i Polska: Konfrontacja i grawitacja. Historia. Kultura. Literatura. Polityka, s. 181-216; А.В. Л и п а то в, Пуикин и Мицкевич: два типа национальной проекций европеизма. Адам Мицкевич и польский романтизм в русской культуре, Москва 2007.

12 А.И. Гер це н, Избранные филозовские произбедения, Т. II, Москва 1948, С. 140. 
tego, że zachwyca się wrogami, którzy za chwilę zabiją legendarnego bohatera rosyjskiego. Tak w wieku XIX - wkrótce po zdławieniu powstania listopadowego - powtarza się sytuacja znana z wieku XVII: twórcy widowiska są zafascynowani artystyczną kulturą wrogów, zaś widownia - obyczajowością polską. I znów jak dwieście lat wcześniej Muzy okazały się silniejsze od Marsa.

W swej istocie wewnętrznej jest to kolejny przejaw prawidłowości ogólnej: kultura (w szczególności kultura artystyczna) góruje nad polityką, a to warunkuje ciągłą obecność polskości w rosyjskości i jej oddziaływanie od wieku XVII po dziś dzień. W XIX w. polskość weszła w rosyjskie życie światowe i rosyjską kulturę muzyczną. Bale w pałacach carskich i dworach szlacheckich zwykle zaczynały się polonezem, a gdy zabawa była w pełni, koniecznie tańczono mazurka. Polonez brzmi w operze P. Czajkowskiego Eugeniusz Oniegin, mazurek w ślad za M. Glinką pojawia się w operze N. Rimskiego-Korsakowa Pan Wojewoda. To są tylko niektóre, może najbardziej jaskrawe, przykłady rozwoju procesu historyczno-kulturowego, który ma swój początek w wieku XVII. Dalszy ciąg znamiennych dla niego zjawisk i prawidłowości jest dość dobrze znany ${ }^{13}$. Stanowią one płaszczyznę tej rosyjsko-polskiej historii, która w swojej istocie jest równoległa, zaś w swoim ukierunkowaniu przeciwstawna płaszczyznom historii państwowej, politycznej, nacjonalistycznej, religijnej.

Realna historia jest wielopłaszczyznowa, jak wielopłaszczyznowa jest realność egzystencji ludzkiej. Ograniczanie historii do jednej z tych płaszczyzn w charakterze wspólnego mianownika zniekształca autentyczną realność, ponieważ sprowadza ją do stanu pars pro toto. Takie postępowanie oznacza wtargnięcie tej czy innej ideologii w myślenie naukowe. Ideologia manipuluje świadomością. Absolutyzując wydźwięk i sens wybranych - państwowych, politycznych, narodowych, religijnych - wydarzeń z przeszłości, aktualizując je zgodnie z potrzebami kolejnej władzy, ideologia kształtuje opinię społeczną, której ta władza potrzebuje. Stąd nauka kończy się tam, gdzie zaczyna się ideologia.

Rosyjsko-polska historia, jak zresztą każda inna, jest wielopłaszczyznowa, kontrowersyjna, a jakże często dramatyczna czy wręcz tragiczna. Absolutyzacja tych czy innych jej warstw, płaszczyzn albo części składowych zniekształca istotę jej niespójnej całości, która może być w miarę obiektywnie rozpatrzona w optyce cywilizacyjno-kulturowej ${ }^{14}$.

${ }^{13} \mathrm{Z}$ najnowszych publikacji na ten temat warto wymienić wydaną z inicjatywy i staraniem Stałego Przedstawiciela PAN przy Rosyjskiej Akademii Nauk, prof. M. Wołosa rosyjsko-polską pracę zbiorową Pycckoпольские языковые, литературные и культурные контакты, Москва 2011.

14 А.В. Л и п ат в в, Европейская циивилизация как дифференцированная целостность (Запад и славяне). Мировая экономика и международные отношения, 2007, N. 6; О н же, Польиа-Россия: иивилизационный аспект национального восприятия (В поисках подхода к аксиологическому осмыслению европеизма. Русская культура в польской сознании, Москва 2009; О н же, Культура Руси, России, Украины и Белоруссии в их отношениях с Польшей: от Средневековья до начала XVIII в. (опьт циивилиационно-регионального рассмотрения). Славянский мир в глазах России, Москва 2011; О н же, Стереотипь национального восприятия: специфика наџиональной истории, особенности национальной культуры и адекватная оптика научного рассмотрения, Studia Polonica, Москва 2002; О н же, Национальное - межнациональное универсальное. (Мир натуры и мир культуры: на примере этнического пограничья Польши), Studia polonorossica, К. 80-летию Е.3. Цыбенко, Издательство Московского университета, 2003; О н ж е, Польскость в русскости: разнонаправленный параллелизм в восприятии культуры западного соседа (Государство и гражданское общество. Россия - Польша. Образы и стереотипы в литературе и культуре, Москва 2002; О н же, Две проекции национального восприятия: Польша глазами Пушкина. Россия глазами Мицкевича стеоретические исторические аспекты межнациональной перцепции). Россия в глазах славянского мира, Москва 2007; Он же, Универсальное национальное. Казус Гоголя. Н.В. Гоголь и славянские 
Właśnie taka optyka umożliwia zrozumienie poszczególnych płaszczyzn ludzkiej egzystencji - zbiorowej i indywidualnej - jako pochodnych uniwersalnej aksjologii Christianitas i ich lokalnych, narodowych refrakcji. Sama zaś kultura stanowi ten czynnik, który warunkuje właściwości wszystkich sfer działalności ludzkiej.

Takie ujmowanie specyfiki kulturowej sprzyja uświadomieniu sobie historii - w tym również rosyjsko-polskiej - poza ideologicznym dysonansem, stwarzającym taką wizję dziejów, w której prawidłowości przemienia się w paradoks. Stąd logiczna konkluzja. Cywilizacyjno-kulturowe podejście pozwala uświadomić sobie oczywisty fakt: polonofilstwo rosyjskie to lokalny (czyli narodowy) przejaw postrzegania, przyswojenia sobie, i wynikającego stąd narodowego rozwoju uniwersalnych wartości we wspólnym dla Rosjan i Polaków kręgu cywilizacyjnym. W przeciągu całej polsko-rosyjskiej historii takie polonofilstwo było ogniwem łączącym rosyjskość z polskością, zaś poprzez nią - z europeizmem. Na przestrzeni już czterech stuleci przejawia się to tak w konkretnych faktach, jak w osobliwości wypowiedzi o nich polonofilów rosyjskich.

„Potrzebowaliśmy okna na Europę i język polski takie okno otworzył” - stwierdził nasz noblista J. Brodski. W 1988 roku w Turynie, występując z odczytem, powiedział słuchaczom: „W stopniu najwyższym wspaniała poezja naszego stulecia jest napisana w języku polskim"15. Brodski, tłumacz szeregu utworów polskich poetów, a wśród nich C.K. Norwida, L. Staffa, K.I. Gałczyńskiego, Z. Herberta i swojego starszego przyjaciela Cz. Miłosza - zaznaczył: „Myślę, że Polacy to w ogóle najmądrzejszy naród, i tak było zawsze. Oni jedyni swego rodzaju prawdziwi Europejczycy"16.

W kontekście przedstawionych tu rozmyślań ta konstatacja wywołuje skojarzenie z sądem amerykańskiej badaczki E. Thompson: „Co cywilizacja myśli o sobie samej i jakie mierniki ona stosuje, określając prawdę i fałsz, często można dowiedzieć się z literatury, którą wydaje na świat"17.

Czyż nie jest to klucz kulturowo-historyczny, co to wbrew nawykom myślowym, zadawnionym uprzedzeniom i tradycyjnym stereotypom wyobrażeń otwiera przed nami taką ogólnocywilizacyjną perspektywę, która umożliwia wzajemne zrozumienie, a przez to wzajemne zbliżenie. W naszej wspólnej - jak to orzekł Cz. Miłosz - „rodzinnej Europie”?

Aleksander W. Lipatow

\section{Russianness and Polishness in the Light of Civilization Axiology of Europeanism}

\section{Summary}

In the twentieth century, two world wars and mass genocides, committed by totalitarian regimes, destroyed natural human rights and suppressed people's personalities, becoming a self-contradiction of civilization. These pan-European processes left their mark on local processes which

литературы, Москва 2012. (Polska wersja: Mikołaj W. Go go 1, Ukraińskość, rosyjskość, polskość w pryzmacie uniwersum cywilizacyjnego, [w:] Idea i komunikacja w języku i kulturze rosyjskiej, pod redakcją A. Dudka, Wydawnictwo Uniwersytetu Jagiellońskiego 2010).

15 „Знамя”, 1988, N. 2, С. 42.

16 И. Бр од с ки й, Большая книга интервью, Москва 2000, С. 602.

17 Е. Том п о н, Генрик Сенкевич, Алексей Толстой и „Столкновение цчивилизации” Сэмюэла Хантингтона // Историк и художник. Польша - Россия, 2008, N. 1-2, С. 171. 
derived from them. The difficult Russian-Polish neighborhood is nothing else but a local manifestation of the pan-European history of the twentieth century.

The situation was different in the Renaissance and Baroque periods. It was then, in the seventeenth century, that Poland gained a predominant role as a mediator in Russia's attempts to bring its protracted era of Middle Ages to an end. The essence of this phenomenon was embedded in the fact that for Russianness, Polishness was a mirror of contemporary Europeanism, and, at the same time, a model of its adjustment to the culture of their Slavic neighbor. In the eighteenth century, as a result of levelling out the high Russian and Polish culture, the role of the latter as a mediator and a model ceased to give way to equal partnership. The implementation of universal ideas of the Enlightenment era and Poles' desire to regain independence were understandable and close to the hearts of representatives of the Russian civil society. This very kind of Europeanism connected Russians and Poles in the sphere of culture, and, subsequently, the politics as its derivative.

Key words: Europeism, Russianness, Polishness, pro-Polish sentiment in Russia 